\title{
Influence of chromium in Laguncularia racemosa (L). Gaertn f. physiology
}

\section{Andréa C. Rocha ${ }^{1}$, Emerson C. Canal ${ }^{1}$, Eliemar Campostrini², Fabrício 0. Reis ${ }^{3}$ and Geraldo Rogério F. Cuzzuol ${ }^{* 3}$}

\footnotetext{
${ }^{1}$ Programa de Pós-Graduação em Biologia Vegetal (PPGBV) da Universidade Federal do Espírito Santo (UFES), Av. Fernando Ferrrari 514, Campus Universitário Alaor Queiroz de Araújo, 29075-910 Vitória ES.

${ }^{2}$ Professor do Setor de Fisiologia Vegetal da Universidade Estadual Norte Fluminense (UENF), Av. Alberto Lamego, CEP 28015620, Campos dos Goytacazes, RJ.

${ }^{3}$ Professor do Departamento de Ciências Biológicas/CCHN/UFES.
}

* Corresponding author: gcuzzuol@gmail.com.

Received: 27 February 2009; Returned for revision: 02 July 2009; Accepted: 02 July 2009

\begin{abstract}
(Influence of chromium in Laguncularia racemosa (L.) Gaertn f. physiology). Most studies of chromium have been realized in the sediments and in mangrove trees. However, little is known about its effect on growth and metabolism in this vegetation. L. racemosa plants were grown in solution with $20 \%$ of ionic strength of Hoagland and Arnon containing $100 \mathrm{mM} \mathrm{NaCl}$ and supplemented with $0.00,0.05$ and $0.50 \mathrm{mg} \mathrm{L}^{-1}$ of $\mathrm{Cr}^{+3}$. The growth, the pigments and gas exchange measurements showed no changes in response to doses of chromium. After 30 days the initiation of treatments, plants of $L$. racemosa had average $0.559 \mathrm{~g}$ of total dry weight, $1.34 \mathrm{mg} \mathrm{L}^{-1}$ of total chlorophyll and $7.9 \mu \mathrm{mol} \mathrm{m}^{-2} \mathrm{~s}^{-1}$ of $A$ ( $\mathrm{CO}_{2}$ photosynthetic assimilation). The photochemical potential efficiency was affected by the intermediate dose of $0.05 \mathrm{mg} \mathrm{L}^{-1}$ of $\mathrm{Cr}^{+3}(\mathrm{Fv} / \mathrm{Fm}=0.73)$ and it was associated with improved translocation of chromium from root to leaves. L. racemosa accumulated $\mathrm{Cr}^{+3}$ in the root, especially in the highest dose (560 $\mathrm{mg} \mathrm{g}^{-1} \mathrm{DW}$ ) representing twenty-eight times the value obtained in control. The concentration of chromium in stem and leaves was not influenced by the tested doses. There was a reduction of fructose and sucrose in the largest dose of chromium, suggesting the drain of these carbohydrates to meet the energy demand of root absorption. The results suggest that $L$. racemosa owns characteristics of a chromium-tolerant species.
\end{abstract}

Keywords: Carbohydrates, fluorescence, gas exchange, growth, heavy metal, mangrove.

\section{INTRODUCTION}

Mangrove ecosystems are widely distributed in tropical, which is settled in marshy soils and influenced direct of tides (MacFarlane, Koller and Blomberg, 2007). It is developed for large areas hacking by several rivers, canals and lakes, in regions generally flat, coastal and tropical climate. They are highly productive and play a vital role as a major primary producer within estuarine systems. Mangrove systems serve as habitat and nursery area for many juvenile fish, crustaceans and mollusks of interest both social and economic (Ramos and Geraldo, 2007). In addition to its ecological importance, the mangrove plays the role of filter in the purification of water, keeping in the plant roots the organic materials and metals transported by estuarine waters (Macfarlane et al., 1999). Thus, mangrove systems act as a reservoir of metals and values of metals in soil at concentrations considered harmful to living organisms (Schaeffer-Novelli, 1995; Vannucci, 2001).

The tolerance has been in part attributed to the ability of mangroves to exclude metals or regulate uptake of metals 
in the root and limit translocation to the shoot (MacFarlane, Pulkownik and Burchett, 2003). A number of studies have found metals to be accumulated predominantly in root tissue, rather than in foliage (Peters et al., 1997; MacFarlene, Koller and Blomberg, 2007). The data seem to suggest that concentrations of translocated metals are low with bioconcentration factors (BCF; ratio of leaf metal to corresponding sediment metal concentration) ranging from $<0.01$ to 0.06 for mangrove trees (Lacerda, 1997). Other studies suggest that mangroves may accumulate and translocate some metals with leaf BCFs greater than one (Chen et al., 2003) thereby meeting established criteria for hyperaccumulating species (Baker and Whiting, 2002).

The high organic matter content, iron oxides, aluminum and manganese as well as the presence of humic acids associated with low cation exchange capacity and the low redox potential, also contribute to the complexation of heavy metals in sediments of mangroves (Ong Che, 1999; Preda and Cox, 2002; Ramos e Silva et al., 2006). This interaction allows the expression of multiple plasticity of vegetation, increasing the tolerance to high levels of metals (Cuzzuol and Campos, 2001).

It is recognized that the tolerance to metals is related to the partitioning of elements in different plant organs and cellular components (Chiu and Chou, 1991). Another form of tolerance is the excretion of metal by glands located on the leaves and/or regulation of the absorption and excretion by the root system (Bernini et al., 2006).

Most studies of chromium are limited to analyzing the sediment or the internal concentration in different plant organs. When the issue is the effect of this metal in plant growth and cell metabolism in coastal environments plants, little is known.

Chromium is not considered an essential trace element, without any participation in the plant metabolism (Dixit et al., 2002). However, at toxic levels, it can affect growth and cause permanent damage to the root system (Scoccianti et al., 2006). Inhibition of seed germination, degradation of photosynthetic pigments, changes in nutrient balance and induction of oxidative stress are other effects on plants under toxic effect of chromium (Panda, 2003).

A real understanding of the physiological mechanisms of plants under the influence of chromium is of great importance to the environmental biomonitoring and the conservation of coastal resources, especially the mangrove trees of the region exposed to chromium at high levels, taking $0.05 \mathrm{mg} \mathrm{L}^{-1}$ as the limit base permitted by Brazilian legislation for estuarine and marine water (CONAMA, 2005). Considering that chromium is one of the most abundant heavy metals in the estuarine ecosystem of Vitória Island, Brazil (Jesus et al., 2004), there is a lack of information on the impact of this element in mangrove. Thus, this study aims to evaluate the effect of chromium on plant growth and carbon metabolism of $L$. racemosa.

\section{MATERIAL AND METHODS}

Plant material and experimental design: Robust and homogenous plants of Laguncularia racemosa (L.) Gaertn. f., containing three pairs of leaves, $10 \pm 0.5 \mathrm{~cm}$ of lenght and $0.426 \pm 0.085 \mathrm{~g}$ of total dry weight, were collected in Dom Luiz Gonzaga Fernandes Natural Hall Park (20¹9'09"S, $40^{\circ} 20^{\prime} 50^{\prime}$ 'W), located in Lameirão Ecological Station, Vitória city, Espírito Santo State, Brazil.

One hundred and fifty plants were carefully removed from the sediment and immediately immersed in distilled water, rinsed in running water and transferred to plastic pots (1L) containing Hoagland and Arnon (1938) solution $20 \%$ of ionic strength in hydroponic system with constant aeration, under environmental temperature and photoperiod in greenhouse with $50 \%$ of shade. The nutrient solution was changed weekly, and after thirty days the dead plants were discarded. From the initial batch, seventy-nine plants with good morphological appearance were cultivated during three weeks in $20 \%$ of Hoagland solution containing $100 \mathrm{mM}$ of $\mathrm{NaCl}$ and $5.5 \mathrm{pH}$ as preliminary results and compatible to the estuarine environments where the values vary from 7 and 514 $\mathrm{mM}$ of $\mathrm{NaCl}$ (Sobrado, 2004).

After this period of adjustment, the treatments with $\mathrm{Cr}^{+3}$ at concentrations of $0.00,0.05$ and $0.50 \mathrm{mg} \mathrm{L}^{-1}$ were performed using as source the basic chromium sulphate $\left(\mathrm{Cr}_{2}(\mathrm{OH})_{2}\left(\mathrm{SO}_{4}\right)_{2}\right)$, normally used in tanning. The experimental design was built up with randomized blocks and each plot was formed by two black plastic pots $(1 \mathrm{~L})$ covered with a perforated styrofoam support with four plants per pot totaling 24 plants per treatment. Weekly, the solutions were exchanged to prevent the salinization, the depreciation of the chemical elements and the chromium concentration increase. 
Analysis of growth: After 30 days, three plants per plot were randomly selected for growth analysis, measuring the length of stem, number of leaves, number of internodes, total leaf area, and fresh and dry weight of plant organs. The biological material was packaged in oven at $60^{\circ} \mathrm{C}$ up to obtaining the constant mass. The leaf area was measured using the LI-COR $3100 \mathrm{C}$ area meter. With these data, it was determined the reason root:shoot, leaf area ratio $(L A R=A / M)$ with the values of leaf area and total dry weight of the plant and also the specific leaf weight (SLW $=M / A)$ measured by the ratio of leaf dry weight and total leaf area (Hunt, 1978).

Pigments, gas exchange and potential photochemical efficiency: The levels of total chlorophyll, chlorophyll $a$, chlorophyll $b$ and carotenoid pigments were determined by the method of Arnon (1949). Samples of $1 \mathrm{mg}$ of the first fully expanded leaf apical were homogenized with pistil in $10 \mathrm{ml}$ of acetone $80 \%(\mathrm{v} / \mathrm{v})$ for extraction of pigments. The operation was performed under low light and temperature to prevent the chlorophyll degradation by light or by enzymatic action. The reading was held in spectrophotometer to estimate the levels of chlorophyll $a$, chlorophyll $b$ and carotenoids. The calculations were made based on equations derived by Hendry and Grime (1993) and the concentration of pigments was expressed in mg.g FW'1.

Chlorophyll a $\left(\mathrm{mg}^{-1} \mathrm{~g}^{-1}\right)=\left[\left(12.7 \times \mathrm{A}_{663}-2.69 \times \mathrm{A}_{645}\right) / 1000 \mathrm{FW}\right] \times \mathrm{V}$ Chlorophyll $b\left(\mathrm{mg}^{-1} \mathrm{~g}^{-1}\right)=\left[\left(22.9 \times \mathrm{A}_{645}-4.68 \times \mathrm{A}_{663}\right) / 1000 \mathrm{FW}\right] \times \mathrm{V}$ Totalchlorophyll $\left(\mathrm{mg} \mathrm{g}^{-1}\right)=\left[\left(8.02 \times \mathrm{A}_{663}+20.2 \times \mathrm{A}_{645}\right) / 1000 \mathrm{FW}\right] \mathrm{XV}$

The carotenoid concentrations were determined by the equation of Price and Hendry (1995) for quantification of carotenoids $\left(\mu \mathrm{mol}_{\mathrm{gFW}} \mathrm{gF}^{-1}\right)=\left[\left(\mathrm{A}_{480}+0.114 \times \mathrm{A}_{663}\right)-(0.638 \mathrm{x}\right.$ $\left.A_{645}\right) \times V / 112.5 \times F W$ of the leaf $\left.(g)\right]$, where $V=$ volume of the sample $(\mathrm{ml}), A=$ absorbance and $F W=$ fresh weight.

Using the SPAD chlorophyll meter of Minolta (Soil Plant Analysis Development), four readings in four different points of the leaves were made, two readings near the apex and two near the base on both sides of the leaf. The measure system used was the average among the four leaf values, totalizing 36 readings, four for each treatment in the third leaf node completely expanded.

Measurements of gas exchange were performed on the same leaves where the analysis of pigments and other assessments were made. The $\mathrm{CO}_{2}$ photosynthetic assimilation
$(A)$, stomatal conductance $\left(g_{s}\right)$, transpiration $(E)$ and leaf to air vapor pressure deficit $\left(D P V_{\text {leat-air }}\right)$ were determined using a portable system of gas exchange measurements, model LI-6200 (LI-COR, Lincoln, NE, USA), on leaves of the third pair completely expanded, counted from the apex. The determinations were made at 8:00 $\mathrm{h}$ in the morning by applying photosynthetic active radiation of $500 \mu \mathrm{mol} \mathrm{m}^{-2} \mathrm{~s}^{-1}$ and concentration of environmental $\mathrm{CO}_{2}$.

The potential photochemical efficiency measurements were performed on the same leaves and at the same time using the non-modulated Fluorimeter, model SAP (Hanstech, King's Lynn, Norkfolk, UK) that determines the characteristics of rapid fluorescence - initial fluorescence $(F 0)$, maximum fluorescence $(F m)$, variable fluorescence $(F v)$ and photochemical efficiency of photosystem II $(F v / F m)$. After 30 minutes of adaptation to darkness, each leaf disc was exposed to a pulse of saturation of luminous intensity equal to $1680 \mu \mathrm{mol} \mathrm{m}^{-2} \mathrm{~s}^{-1}$ during five seconds.

Soluble non-structural carbohydrates: Leaf segments were homogenized in nitrogen liquid and the extraction of nonstructural carbohydrates was made in $80 \%$ ethanol to $70^{\circ} \mathrm{C}$. The determination of glucose, fructose and sucrose followed the enzymatic method, reducing $\mathrm{NAD}^{+}$estimated at $340 \mathrm{~nm}$ by Elisa reader (Stitt et al., 1989). Aliquots of the samples were homogenized with buffer (100 mM imidazole pH 7.4, $5 \mathrm{mM} \mathrm{MgCl} 2,2 \mathrm{mM} \mathrm{NAD}{ }^{+}, 1 \mathrm{mM}$ ATP and $2 \mathrm{U}$ of $\mathrm{G}_{6} \mathrm{PDH}$ ), adding $1.5 \mathrm{U}$ of hexokinase for the estimation of glucose. $3 \mathrm{U}$ of phosphoglucose isomerase has been added for determination of fructose while sucrose was determined by appending $5 \mathrm{U}$ of $\beta$-fructosidase. In the end of this reaction, $3 \mathrm{U}$ of phosphoglucose isomerase was added to estimate the sucrose through the activity of $\beta$-glucofrutose.

Internal concentration of chromium: Two plants per plot, totalizing 18 samples per treatment, were dried in paper filter for 24 hours. The roots, the stems and leaves were separated, washed and dried in oven $\left(60^{\circ} \mathrm{C}\right)$, then ground, sieved in a 1.0 $\mathrm{mm}$ mesh and stored in glass flasks at ambient temperature. The extraction of chromium was performed by acid digestion in nitric acid and perchloric acid in a cold digester tube for three to four hours. After this period, the material ( $1 \mathrm{~g} \mathrm{DW}$ ) was transferred to the digester block and the temperature was increased gradually to $160^{\circ} \mathrm{C}$ for 40 minutes and then $210^{\circ} \mathrm{C}$ for 20 minutes, as the method described by Silva (1999). The concentration of chromium was determined by atomic 
absorption spectrophotometer (AAS) using a hollow cathode lamp of chromium as an energy source. A calibração do equipamento, em cada troca de lâmpada, foi realizada utilizando padrões a partir de soluções estoques. The calibration of the equipment in exchange for each lamp was made using patterns from stock solutions (50 ppm $\pm 0.5 \%$ ).

Statistical analysis: Data were submitted to analysis of variance (ANOVA) using the program ASSISTAT version 7.4 beta (Silva and Azevedo, 2007), and the Tukey test at $5 \%$ of probability was applied when necessary. For the analysis of the $\mathrm{Cr}^{+3}$ effect in gas exchange, the photochemical efficiency, the concentration of pigments and carbohydrates and analysis of plant growth was applied randomized blocks, and the double factorial scheme was applied for internal analysis of $\mathrm{Cr}^{+3}$.

\section{RESULTS AND DISCUSSION}

Analysis of growth: There were no significant differences in growth measurements, as well as the ratio root: shoot and the LAR, SLW and SLA in plants of $L$. racemosa treated with and without $\mathrm{Cr}^{+3}$ (Table 1). The pattern of dry weight partition also showed no variation. The occurrence of toxicity in plants is rare due to the low mobility of $\mathrm{Cr}^{+}$through the cell membrane (Panda and Choudhury, 2005). This lack of effect on growth can be associated with the extent chromium concentration used, since inhibitory effects on growth were only found in concentrations higher than $100 \mathrm{mM}$ of chromium (Panda and Choudhury, 2005) highly toxic even for plants that live in a anoxic environment as $L$. racemosa.

Table 1 - Growth measurements of $L$. racemosa cultivated in hydroponic solution with $20 \%$ of ionic strength of Hoagland and Arnon (1938) supplemented with 0.00 , 0.05 and $0.50 \mathrm{mg} \mathrm{L}^{-1} \mathrm{Cr}^{+3}$. Letters compare the different values between the concentrations of $\mathrm{Cr}^{+3}$, and \pm represents standard error $(P<0.05$ and $n=9)$.

\begin{tabular}{cccc}
\hline \multirow{2}{*}{ Growth Measurements } & & $\mathrm{Cr}^{+3}\left(\mathrm{mg} \mathrm{L}^{-1}\right)$ & 0.50 \\
\cline { 2 - 4 } & 0.00 & 0.05 & $0.172 \pm 0.05 \mathrm{a}$ \\
Root dry weight $(\mathrm{g})$ & $0.184 \pm 0.02 \mathrm{a}$ & $0.128 \pm 0.08 \mathrm{a}$ & $0.176 \pm 0.09 \mathrm{a}$ \\
Stem dry weight $(\mathrm{g})$ & $0.192 \pm 0.06 \mathrm{a}$ & $0.140 \pm 0.05 \mathrm{a}$ & $0.238 \pm 0.07 \mathrm{a}$ \\
Blade dry weight $(\mathrm{g})$ & $0.245 \pm 0.02 \mathrm{a}$ & $0.183 \pm 0.09 \mathrm{a}$ & $0.010 \pm 0.0 \mathrm{a}$ \\
Petiole dry weight $(\mathrm{g})$ & $0.014 \pm 0.00 \mathrm{a}$ & $0.008 \pm 0.00 \mathrm{a}$ & $0.325 \pm 0.08 \mathrm{a}$ \\
Shoot dry weight $(\mathrm{g})$ & $0.431 \pm 0.05 \mathrm{a}$ & $0.443 \pm 0.08 \mathrm{a}$ & $0.596 \pm 0.07 \mathrm{a}$ \\
Total dry weight (g) & $0.638 \pm 0.02 \mathrm{a}$ & $15.1 \pm 2.8 \mathrm{a}$ & $14.7 \pm 3.2 \mathrm{a}$ \\
Stem length $(\mathrm{cm})$ & $16.3 \pm 1.5 \mathrm{a}$ & $1.82 \pm 0.1 \mathrm{a}$ & $2.20 \pm 0.1 \mathrm{a}$ \\
Stem diameter $(\mathrm{mm})$ & $2.08 \pm 0.1 \mathrm{a}$ & $7 \pm 1.6 \mathrm{a}$ & $7 \pm 0.8 \mathrm{a}$ \\
Leaves number & $8 \pm 1.5 \mathrm{a}$ & $28.3 \pm 9.4 \mathrm{a}$ & $37.1 \pm 6.8 \mathrm{a}$ \\
Leaf area $\left(\mathrm{cm}^{2}\right)$ & $37.1 \pm 5.8 \mathrm{a}$ & $0.39 \pm 0.0 \mathrm{a}$ & $0.42 \pm 0.0 \mathrm{a}$ \\
Root:shoot ratio & $0.38 \pm 0.0 \mathrm{a}$ & $6.41 \pm 0.4 \mathrm{a}$ & $6.21 \pm 0.8 \mathrm{a}$ \\
SLW $\left(\mathrm{g} \mathrm{cm}^{-2}\right)$ & $6.69 \pm 0.5 \mathrm{a}$ & $159 \pm 8.7 \mathrm{a}$ & $162 \pm 7.3 \mathrm{a}$ \\
SLA $\left(\mathrm{cm}^{2} \mathrm{~g}^{-1}\right)$ & $150 \pm 9.5 \mathrm{a}$ & $64 \pm 5.8 \mathrm{a}$ & $60 \pm 6.5 \mathrm{a}$ \\
LAR $\left(\mathrm{cm}^{2} \mathrm{~g}^{-1}\right)$ & $60 \pm 3.5 \mathrm{a}$ & & \\
\hline
\end{tabular}

\section{Pigments, gas exchange and potential photochemical}

efficiency: Reduction in concentration of photosynthetic pigments in plants under the influence of heavy metals has been reported in some genotypes (Panda and Parta, 2000; Panda, 2003; Baker and Rosenqvist, 2004). However, in native plants such as the ones from mangrove ecosystem, heavy metals accumulated in leaf tissues did not affect the content of chlorophyll and carotenoids showing no visible signs of toxicity (Macfarlane et al., 2003). Similarly, the pigments in $L$. racemosa were not affected by $\mathrm{Cr}^{+3}$ (Figure 1, Table 2), both by the method of extraction as the SPAD, suggesting that the species in hydroponic cultivation is tolerant and well adapted to the levels of $\mathrm{Cr}^{+3}$ tested. The values of $A, g s, E$ and $\mathrm{DPV}_{\text {leat-air }}$ (Table 3 ) did not vary between treatments, thus $L$. racemosa did not show any variation in gas exchange. Perhaps, as this species accumulates $\mathrm{Cr}^{+3}$ to its roots, there was no negative influence on gas exchange, since the deleterious effects of heavy metal would be more intense in the leaves. 

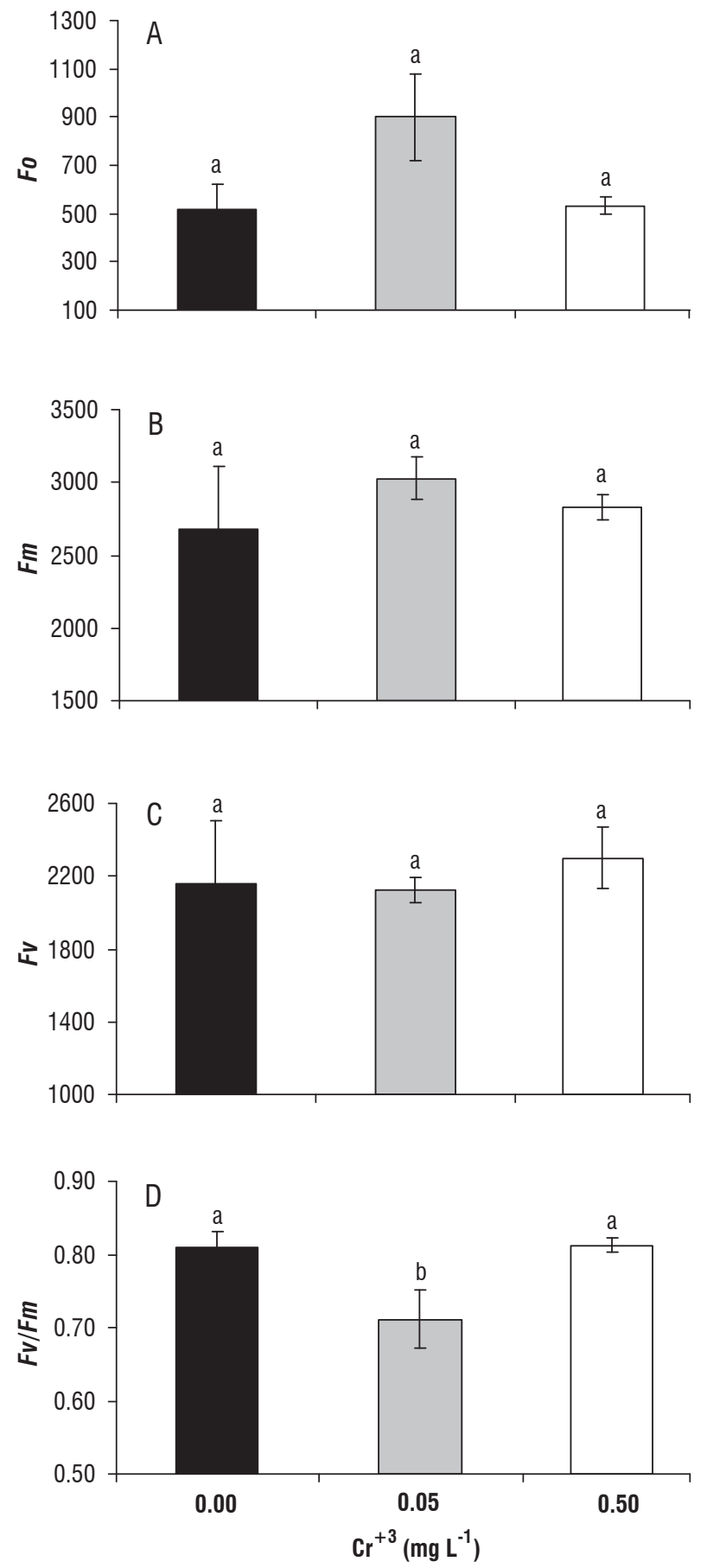

Figure 1. Values of $(\mathbf{A})$ initial fluorescence $\left(F_{0}\right),(\mathbf{B})$ maximum fluorescence $\left(F_{m}\right)$, (C) variable fluorescence $\left(F_{v}\right)$ and (D) PSIl photochemical efficiency (Fv/ $F m$ ) in $L$. racemosa seedlings cultivated in hydroponic solution with $20 \%$ of ionic strength solution of Hoagland and Arnon (1938) supplemented with 0.00 , 0.05 and $0.50 \mathrm{mg} \mathrm{L}^{-1}$ of $\mathrm{Cr}^{+3}$. Letters compare the different values between the concentrations of $\mathrm{Cr}^{+3}$, and \pm represents standard error $(P<0.05$ and $n=6)$.
Table 2 - Average values of chlorophyll $a$, chlorophyll $b$, total chlorophyll $\left(\mathrm{mg} . \mathrm{g}^{-1}\right)$, the chlorophyll a/chlorophyll $b$ ratio, carotenoids $\left(\mu \mathrm{mol} . \mathrm{g}^{-1}\right)$ and chlorophyll analyzed with SPAD in L. racemosa seedlings cultivated in hydroponic solution with $20 \%$ of ionic strength solution of Hoagland and Arnon (1938) supplemented with $0.00,0.05$ and $0.50 \mathrm{mg} \mathrm{L}^{-1} \mathrm{of} \mathrm{Cr}^{+3}$. Letters compare the different values between the concentrations of $\mathrm{Cr}^{+3}$, and \pm represents standard error $(P<0.05$ and $n=6)$.

\begin{tabular}{cccc}
\hline \multirow{2}{*}{ Pigments } & \multicolumn{3}{c}{$\mathrm{Cr}^{+3}\left(\mathrm{mg} \mathrm{L}^{-1}\right)$} \\
\cline { 2 - 4 } & 0.00 & 0.05 & 0.50 \\
\hline Chlorophyll a & $0.64 \pm 0.05 \mathrm{a}$ & $0.60 \pm 0.05 \mathrm{a}$ & $0.60 \pm 0.05 \mathrm{a}$ \\
Chlorophyll $b$ & $0.76 \pm 0.06 \mathrm{a}$ & $0.70 \pm 0.03 \mathrm{a}$ & $0.73 \pm 0.05 \mathrm{a}$ \\
Total chlorophyll & $1.40 \pm 0.11 \mathrm{a}$ & $1.30 \pm 0.11 \mathrm{a}$ & $1.33 \pm 0.11 \mathrm{a}$ \\
Chlorophyll a/b & $0.85 \pm 0.01 \mathrm{a}$ & $0.85 \pm 0.00 \mathrm{a}$ & $0.83 \pm 0.02 \mathrm{a}$ \\
Carotenoids & $0.14 \pm 0.01 \mathrm{a}$ & $0.14 \pm 0.01 \mathrm{a}$ & $0.15 \pm 0.01 \mathrm{a}$ \\
SPAD & $55.8 \pm 2.2 \mathrm{a}$ & $55.3 \pm 2.9 \mathrm{a}$ & $59.6 \pm 3.7 \mathrm{a}$ \\
\hline
\end{tabular}

Table 3 - Average values of $\mathrm{CO}_{2}$ photosynthetic assimilation $(A)$, stomatal conductance $\left(g_{s}\right)$, transpiration $(E)$ and leaf to air vapor pressure deficit $\left(D P V_{\text {leat-air }}\right)$ in $L$. racemosa seedlings cultivated in hydroponic solution with $20 \%$ of ionic strength solution of Hoagland and Arnon (1938) supplemented with $0.00,0.05$ and $0.50 \mathrm{mg} \mathrm{L}^{-1}$ of $\mathrm{Cr}^{+3}$. Letters compare the different values between the concentrations of $\mathrm{Cr}^{+3}$, and \pm represents standard error $(P<0.05$ and $n=6)$.

\begin{tabular}{cccc}
\hline \multirow{2}{*}{ Gas exchange } & \multicolumn{3}{c}{$\mathrm{Cr}^{+3}\left(\mathrm{mg} \mathrm{L}^{-1}\right)$} \\
\cline { 2 - 4 } & 0.00 & 0.05 & 0.50 \\
\hline$A\left(\mu \mathrm{mol} \mathrm{m}{ }^{-2} \mathrm{~s}^{-1}\right)$ & $8.50 \pm 0.5 \mathrm{a}$ & $7.20 \pm 0.8 \mathrm{a}$ & $8.00 \pm 0.6 \mathrm{a}$ \\
$g_{s}\left(\mathrm{~mol} \mathrm{~m}^{-2} \mathrm{~s}^{-1}\right)$ & $0.31 \pm 0.0 \mathrm{a}$ & $0.31 \pm 0.0 \mathrm{a}$ & $0.27 \pm 0.0 \mathrm{a}$ \\
$E\left(\mathrm{mmol} \mathrm{m}{ }^{-2} \mathrm{~s}^{-1}\right)$ & $8.05 \pm 0.8 \mathrm{a}$ & $8.13 \pm 0.5 \mathrm{a}$ & $7.84 \pm 0.9 \mathrm{a}$ \\
$D P V_{\text {leaf-air }}(\mathrm{kPa})$ & $3.23 \pm 0.3 \mathrm{a}$ & $3.25 \pm 0.5 \mathrm{a}$ & $3.55 \pm 0.8 \mathrm{a}$ \\
\hline
\end{tabular}

The low value of $F v / F m$ at $0.05 \mathrm{mg} \cdot \mathrm{L}^{-1}$ of $\mathrm{Cr}^{+3}$ in relation to the other doses tested (Figure 2) shows slight decrease in photochemical efficiency due to a low inhibiting in absorption and transfer of light energy to the centers of reaction and low reoxidation electrons acceptors from plastoquinones. The slight reduction in photosynthetic efficiency $(F v / F m)$ at 0.05 $\mathrm{mg} . \mathrm{L}^{-1}$ of $\mathrm{Cr}^{+3}$ may be caused by the translocation factor (TF) of chromium which is defined as the ratio of the chemical element concentration between the shoot and root (Yu and Gu, 2007). In low concentrations, the chromium shows more mobility from the root to the leaves (Han et al., 2004). Analyzing the phytotoxic effects of trivalent and hexavalent $\mathrm{Cr}$, Han et al. (2004) found out that, at lower concentration, the $\mathrm{Cr}^{+3}$ focuses less on the root with a higher translocation to the leaves. The $L$. racemosa plants, exposed to higher doses of chromium, showed greater accumulation of that element in the roots (Figure 3). In concentration of $0.50 \mathrm{mg} \mathrm{L}^{-1}$ of $\mathrm{Cr}^{+3}$ the TF was 0.07 while in $0.05 \mathrm{mg} \mathrm{L}^{-1}$ this amount was 0.10 . 


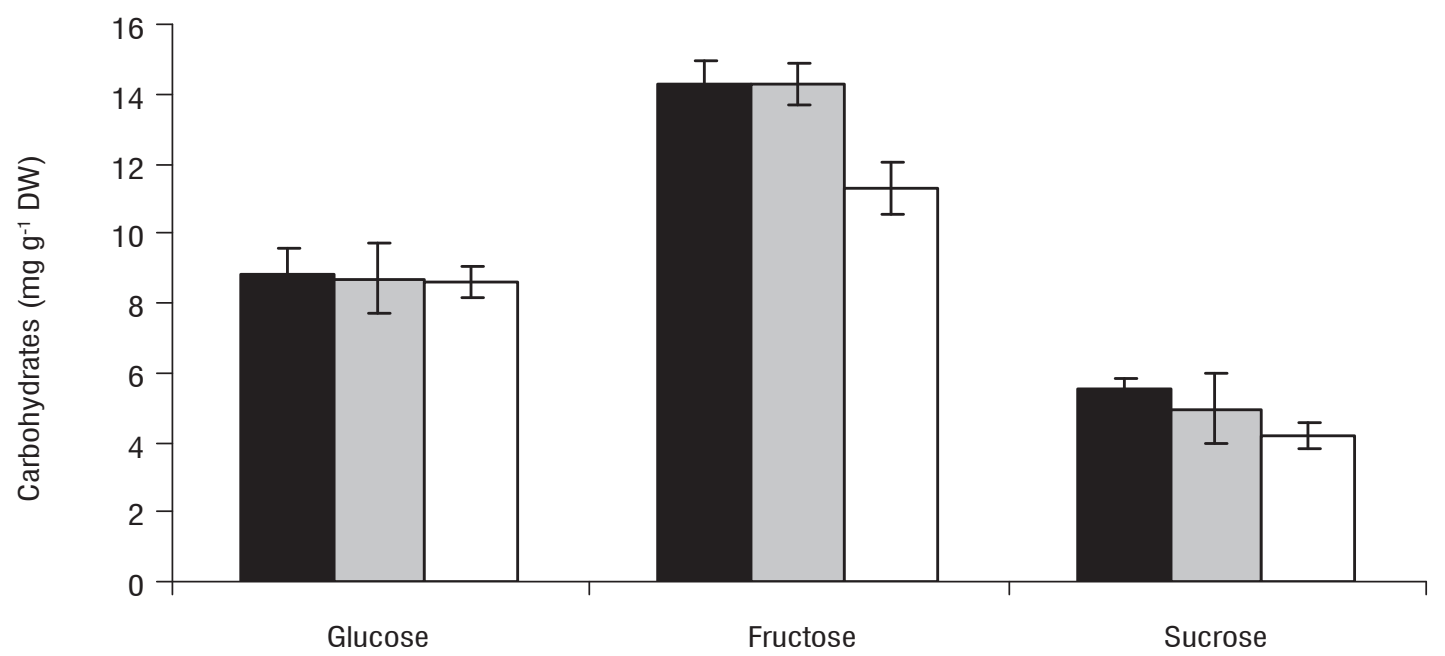

Figure 2. Average values of $\mathrm{Cr}^{+3}$ in root, stem and leaf of $L$. racemosa plants cultivated in hydroponic solution with $20 \%$ of ionic strength solution of Hoagland and Arnon (1938) supplemented with $0.00(\square), 0.05(\square)$ and $0.50(\square) \mathrm{mg} \mathrm{L}^{-1}$ of $\mathrm{Cr}^{+3}$. Capital letters compare the average concentrations of $\mathrm{Cr}$ between plant organs, and lowercase letters compare averages between concentrations of $\mathrm{Cr}$ within each plant organ $(P<0.05$ and $n=18)$.

According to Shanker et al. (2005), the disorganization of the chloroplasts ultra-structure, the electrons transport inhibition and the changes in enzymatic activities of the carbon sequestration are the likely effects of the photosystem II inhibition affected by chromium. Those effects, reflected in the chlorophyll fluorescence, were not observed in $L$. racemosa plants exposed to the dose of $\mathrm{Cr}^{+3}$ considered toxic by Brazilian legislation (CONAMA, 2005). According to this document the concentration $0.05 \mathrm{mg} \mathrm{L}^{-1}$ of total $\mathrm{Cr}$ is determined for brackish and saline water of class 1 (water with primary contact). The mangrove is usually in estuarine areas (presence of brackish water) which are usually practiced fishing activities, with primary contact of people (water for direct and prolonged contact) which do these activities that would characterize as brackish water of class 1 .

However, studies do not state that the $L$. racemosa photosynthetic activity is not affected by the impact of chromium in the environment since some species only showed photosynthetic inhibitory effects when exposed to chromium levels higher than $50 \mathrm{mg} \mathrm{L}^{-1}$ (Dhir et al., 2008).

Soluble non-structural carbohydrates: Similarly to gas exchange and potential photochemical efficiency, chromium had little influence on the carbohydrates metabolism in L. racemosa plants (Figure 3). The sucrose and fructose concentration in leaves showed a slight decrease under higher levels of chromium. Sucrose represented the smallest fraction of soluble carbohydrates analyzed. That could mean higher translocation of sucrose from the source to the drain organ, feeding the energetic demands of chromium active transport in the vacuole of the cortical cells in root system (Mangabeira et al., 2006; Panda and Choudhury, 2005).

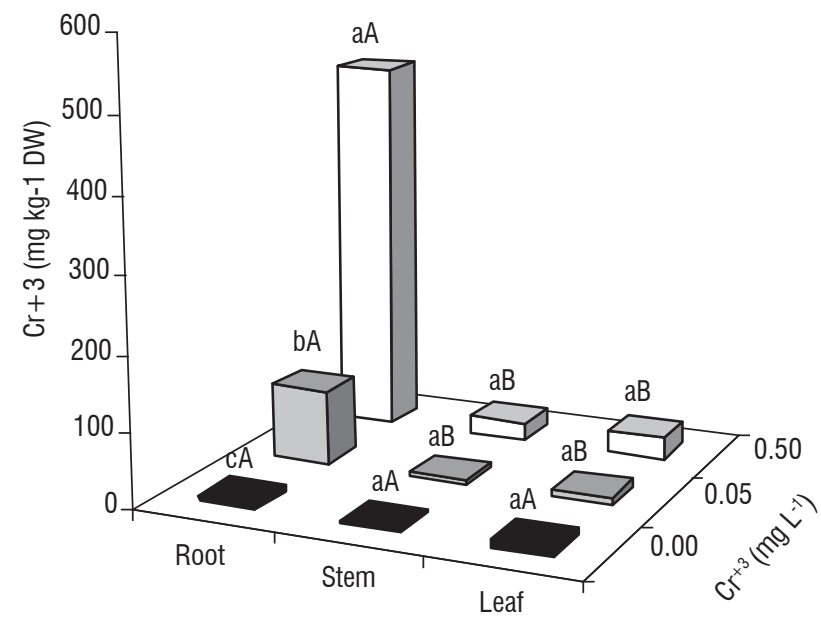

Figure 3. Glucose, fructose e sucrose concentrations in $L$. racemosa leaves cultivated in hydroponic solution with $20 \%$ of ionic strength solution of Hoagland and Arnon (1938) supplemented with $0.00(\square), 0.05(\square)$ and 0.50 ( $\square) \mathrm{mg} \mathrm{L}^{-1}$ of $\mathrm{Cr}^{+3}$. The bars represent standard error $(P<0.05$ and $n=6)$.

Internal concentration of chromium: The roots in 0.05 and $0.50 \mathrm{mg} \mathrm{L}^{-1}$ of chromium accumulated high levels of this metal, followed by low concentrations in leaves and stems (Figure 3). In $0.50 \mathrm{mg} \mathrm{L}^{-1}$ of $\mathrm{Cr}^{+3}$, the roots accumulated almost 
seven times the concentration of chromium in relation to the plants treated with $0.05 \mathrm{mg} \mathrm{L}^{-1}$ of $\mathrm{Cr}^{+3}$, with no significant differences of this element content in leaves. According to Ramos and Geraldo (2007), values of chromium ranging from 2.05 to $8.2 \mathrm{mg} \mathrm{kg}^{-1}$ in leaves of mangrove species can indicate environmental pollution. However, even in control, that amount was $6.9 \mathrm{mg} \mathrm{kg}^{-1}$ in L. racemosa plants, suggesting a revision of the reference values in internal concentration of chromium that are considered critical and indicative of environmental pollution in mangrove.

The low concentration of chromium in leaves of $L$. racemosa in all treatments, including in $0.50 \mathrm{mg} \mathrm{L}^{-1}$ whose value is ten times higher than the limit permitted by federal law to brackish waters as Brazilian legislation (CONAMA 2005), may be due to low efficiency of $\mathrm{Cr}^{+3}$ transfer from root to leaves (Pandey and Sharma, 2003; Maine et al., 2004). According to Mangabeira et al. (2006), this phenomenon characterizes plants under high concentration of chromium. The greatest accumulation of $\mathrm{Cr}^{+3}$ in roots in relation to air organs is common in mangrove species and other biomes (Zengh et al., 1997; MacFarlane et al., 2003; Maine et al., 2004; Yu and Gu, 2007) as well as some agricultural cultivars (Mei et al., 2002; Scoccianti et al., 2006).

In relation to plants developed in situ, the $\mathrm{Cr}^{+3}$ concentration in $L$. racemosa plants grown in hydroponic system was higher. Ong Che (1999) detected values ranging between 2 and $6 \mathrm{mg} \mathrm{kg}^{-1}$ of dry weigh in Kandelia candel roots, a typical mangrove tree. This probably occurred due to the higher $\mathrm{Cr}^{+3}$ availability in hydroponic solution and the lack of reducing processes that normally occur in sediment (Tam and Wong, 1993). Sediment properties as texture, organic matter (OM) and redox potential are involved in the process of metal immobilization in sediments of mangrove ecosystem (Tam and Wong, 1993). Moreover, under natural conditions, the presence of vegetation can be very important in determining the concentration of metals in the sediment (Ong Che, 1999). Areas covered by vegetation have a redox potential higher than those without vegetation due to oxidative processes in roots (Chiu and Chou, 1991).

In $L$. racemosa, the metabolic tolerance to $0.50 \mathrm{mg} \mathrm{L}^{-1}$ of chromium may be due to partitioning of heavy metals in vacuoles of root cells associated with their low mobility to the leaves (Panda and Choudhury, 2005; Dhir et al., 2008). This behavior is itself an efficient mechanism of tolerance in environments contaminated by heavy metals. The formation of iron plaque on roots that can diminish the loss of oxygen is common in aquatic and wetland plants (Møller and SandJensen, 2008) and may influence the availability and mobility of metals in the rhizosphere of aquatic plants (Hansel et. al, 2001). Machado et al. (2005) observed exclusion of metals by formation of iron plaque on roots of $L$. racemosa, what possibly can contribute to the adaptability of plants to flooded environments.

Considering the initial growth phase and the lack of influence of chromium in photosynthetic activity and growth of $L$. racemosa, this tree owns physiological characteristics of phytoremediate species, since $L$. racemosa tolerates chromium levels ten times higher than those permitted by Brazilian legislation (CONAMA, 2005). However, studies about L. racemosa tolerance to chromium could reveal important information about the physiological mechanism of plants in coastal environments facing the environmental impact caused by heavy metals.

\section{REFERENCES}

Arnon DI (1949) Copper enzymes in isolated chloroplast. Polyphenoloxidase in Beta vulgaris. Plant Physiol. 24:1-15.

Baker AJM, Whiting SN (2002) In search of the holy grail - a further step in understanding metal hyperaccumulation? New Phytol. 155:1-4.

Baker NR, Rosenqvist E (2004) Applications of chlorophyll fluorescence can improve $\mathrm{Cr}^{+3}$ on production strategies: an examination of future possibilities. J Exp Bot. 55:1607-1621.

Bernini E, Silva MAB, Carmo TMS, Cuzzuol GRF (2006) Composição química do sedimento e de folhas das espécies do manguezal do estuário do Rio São Mateus, Espírito Santo, Brasil. Revista Brasileira de Botânica. 29:689-699.

Chen XY, Tsang EPK, Chan ALW (2003). Heavy metal contents in sediments, mangroves and bivalves from Ting Kok, Hong Kong. China Environ Sci. 23: 480-484.

Chiu CY, Chou CH (1991) The distribution and influence of heavy metals in mangrove forests of the Tamshui estuary in Taiwan. J Soil Sci Plant Nutr $37: 659-669$

CONAMA (2005) Resolução n 357, de 17 de março de 2005. Conselho Nacional de Meio Ambiente, Brasília - DF.

Cuzzuol GRF, Campos A (2001) Aspectos nutricionais na vegetação de manguezal do estuário do Rio Mucuri, Bahia, Brasil. Revista Brasileira de Botânica. 24:227-234.

Dhir B, Sharmila P, Saradhi PP (2008) Photosynthetic performance of Salvinia natans exposed to chromium and zinc rich wastewater. Braz J Plant Physiol 20:61-70.

Dixit V, Pandey V, Shyam R (2002) Chromium ions inactive electron transport and enhance superoxid generation in vivo in pea (Pisum sativum L. cv:Azad) root mitochondria. Plant Cell Environ. 25:687-693.

Han FX, Sridhar BBM, Monts DL, SU Y (2004) Phytoavailability and toxicity of trivalent and hexavalent chromium in Brassica juncea. New Phytol 162:489499. 
Hansel CM, Fendorf S, Sutton S, Newville M (2001) Characterization of Fe plaque and associated metals on the roots of mine-waste impacted aquatic plants. Environ Sci Technol 35:3863-3868.

Hendry GAF, Grime JP (1993) Methods in Comparative Plant Ecology. Marcel Dekker, New York.

Hoagland DR, Arnon DI (1938) The water-culture method for growing plants without soil. California Agricultural Experimental Station. Circ. n.347.

Hunt R (1978) Plant growth curves: the functional approach to plant growth analysis. Edward Arnold Publishers, London.

Jesus HC de, Costa EA, Mendonca ASF (2004) Distribuicão de metais pesados em sedimentos do sistema estuarino da llha de Vitória-ES. Química Nova. 27:378-386.

Lacerda LD (1997). Trace metals in mangrove plants: why such low concentrations? In: Kjerfve B, Lacerda LD, Diop HS (Eds.). Mangrove Ecosystem Studies in Latin America and Africa. UNESCO, Paris, pp.171178.

Machado W, Silva-Filho EV, Oliveira RR, Lacerda LD (2002) Trace metal retention in mangrove ecosystems in Guanabara Bay, SE Brazil. Marine Pollution Bulletin 44:1277-1280.

Machado W, Gueiros BB, Lisboa-Filho SD, Lacerda LD (2005) Trace metals in mangrove seedlings: role of iron plaque formation. Wetlends Ecology and Management. 13:199-206.

MacFarlane GR, Burchett MD (1999) Zinc distribution and excretion in the leaves of the grey mangrove, Avicennia marina (Forsk.) Vierh. Environ Exp Bot. 41: 167-175.

MacFarlane GR, Pulkownik A, Burchett MD (2003) Accumulation and distribution of heavy metals in the grey mangrove, Avicennia marina (Forsk.) Vierh.: biological indication potential. Environ Pollution. 123:139-151.

MacFarlene GR, Koller CE, Blomberg SP (2007) Accumulation and partitioning of heavy metals in mangroves: a synthesis of field-based studies. Chemosphere. 69:1454-1464.

Maine MA, Suñé NL, Lagger SC (2004) Chromium bioaccumulation: comparison of the capacity of two floating aquatic macrophytes. Water Res 38:1494-1501.

Mangabeira PA, Gavrilov KL, Almeida AAF, Oliveira AH, Severo, MI, Rosa TS, Silva DC, Labejof L, Escaig F, Levi-Setti R, Melke MS, Loustalot FG, Galle P (2006) Chromium localization in plant tissues of Lycopersicum esculentum Mill using ICP-MS and ion microscopy (SIMS). Appl Surface Sci. 252:34883501.

Mei BJ, Puryear JD, Newton RJ (2002) Assessment of $\mathrm{Cr}^{+3}$ tolerance and accumulation in selected plant species. Plant Soil. 247:223-231.

Møller CL, Sand-Jensen K (2008) Iron plaques improve the oxygen supply to root meristems of the freshwater plant, Lobelia dortmanna. New Phytologist. 179:848-856

Ong Che RG (1999) Concentration of 7 heavy metals in sediments and mangrove root samples from Mai Po, Hong Kong. Marine Pollution Bulletin. 39:269-279.

Panda SK (2003) Heavy metal phytotoxicity induces oxidative stress in Taxithelium sp. Curr Sci. 84:631-633.n

Panda SK, Parta HK (2000) Does $\mathrm{Cr}^{+3}$ (III) produces oxidative damage in excised wheat leaves. J Plant Biol. 27:105-110.
Panda SK, Choudhury S (2005) Chromium stress in plants. Braz J Plant Physiol. 17:95-102.

Pandey N, Sharma CP (2003) Chromium interference in iron nutrition and water relations of cabbage. Environ Exp Bot. 49:195-200.

Peters EC, Gassman NJ, Firman JC, Richmond RH, Power EA (1997). Ecotoxicology of tropical marine ecosystems. Environ Toxicol Chem.16:1240.

Preda M, Cox ME (2002) Trace metals occurrence and distribution in sediments and mangroves, Pumicestone region, southeast Queensland, Australia. Environ Internat. 28:433-449.

Price AH, Hendry GA (1995) Iron-catalyzed oxygen radical formation and its possible contribution to drought damage in nine native grasses and three cereals. Plant Cell Environ. 14:246-253.

Ramos MGM, Geraldo LP (2007) Avaliação das espécies de plantas Avicennia schaueriana, Laguncularia racemosa e Rhizophora mangle como bioindicadoras de poluição por metais pesados em ambientes de mangues. Engenharia Sanitária e Ambiental. 12:440-445

Ramos e Silva CA, Da Silva AP, De Oliveira SR (2006) Concentration, stock and transport rate of heavy metals in a tropical red mangrove, Natal, Brazil. Marine Chemistry. 99:2-11.

Scoccianti V, Crinelli R, Tirillini B, Mancinelli V, Speranza A (2006) Uptake and toxicity of $\mathrm{Cr}^{+3}$ in celery seedlings. Chemosphere. 64:1695-1703.

Schaeffer-Novelli Y (1995). Ecossistema entre a terra e o mar. Carabbean Ecological Research, São Paulo.

Shanker AK, Cervantes C, Loza-Tavera H, Avudainayagam S (2005) Chromium toxicity in plants. Environ Intern. 31:739-753.

Silva FC (1999) Manual de análises químicas de solos, plantas e fertilizantes. EMBRAPA, Campinas, SP

Silva FAS, Azevedo CAV (2007) A new version of the Assistat-Statistical Assistance Software. In: World Congress on computers in agriculture 4. Orlando, USA, pp. 393-396.

Sobrado MA (2004) Influence of external salinity on the osmolality of xylem sap, leaf tissue, and leaf gland secretion of the mangrove Laguncularia racemosa (L.) Gaertn. Trees18:422-427.

Stitt M, Lilley RM, Gerhardt R, Heldt HW (1989) Metabolite levels in specific cells and subcellular compartments of plant leaves. Meth Enzymol. 174:518550 .

Tam NFY, Wong YS (1993) Retention of nutrients and heavy metals in mangrove sediment receiving wastewater of different strenghs. Environ Technol. 14:719-729.

Vannucci M. (2001) What is so special about mangroves? Braz J Biol. 61(4): 599-603.

Yu XZ, Gu JD (2007) Accumulation and distribution of trivalent chromium and effects on hybrid willow (Salix matsudana Koidz X alba L.) metabolism. Arch Environ Contam Toxicol. 52:503-511.

Zheng W, Chen X, Peng L (1997) Accumulation and biological cycling of heavy metal elements in Rhizophora stylosa mangroves in Yingluo Bay, China. Marine Ecology Progress Series. 159:293-301. 